\title{
ENERGY SUPPLY AND DEMAND IN THE INTERVERTEBRAL DISC
}

\author{
FORNECIMENTO E DEMANDA DE ENERGIA NO DISCO INTERVERTEBRAL
} SUMINISTRO DE ENERGÍA Y DEMANDA EN EL DISCO INTERVERTEBRAL

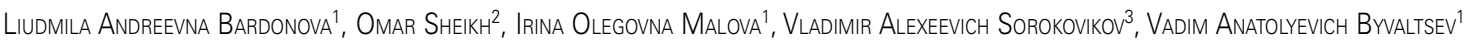 \\ 1. Neurosurgery Department, Irkutsk State Medical University, Ministry of Health, 1 Krasnogo Vosstaniya St., Irkutsk, Russia. \\ 2. School of Chemical, Biological, and Environmental Engineering, Oregon State University, 1500 SW Jefferson St., Corvallis, OR, 97331, USA. \\ 3. Irkutsk Scientific Center of Surgery and Traumatology, Irkutsk, Russia.
}

\begin{abstract}
The intervertebral disc (IVD) is one of the parts of the body most commonly affected by disease, and it is only recently that we have come closer to understanding the reasons for its degeneration, in which nutrient supply plays a crucial role. In this literature review, we discuss the basic principles and characteristics of energy supply and demand to the IVD. Specifically, we review how different metabolites influence IVD cell activity, the effects of mechanical loading on IVD cell metabolism, and differences in energy metabolism of the annulus fibrous and nucleus pulposus cell phenotypes. Determining the factors that influence nutrient supply and demand in the IVD will enhance our understanding of the IVD pathology, and help to elucidate new therapeutic targets for IVD degeneration treatment.
\end{abstract}

Keywords: Intervertebral disc; Nucleus pulposus; Annulus fibrosus; Energy metabolism; Cell therapy.

\section{RESUMO}

O disco intervertebral (IVD) é uma das partes mais comuns do corpo e apenas recentemente nos aproximamos de compreender as razões da sua degeneração, em que o suprimento de nutrientes desempenha um papel crucial. Nesta revisão da literatura, discutimos os princípios básicos e as nuances do fornecimento e da demanda de energia para o IVD. Especificamente, analisamos como os diferentes metabólitos influenciam na atividade das células IVD, os efeitos da carga mecânica no metabolismo das células IVD, a diferença no metabolismo energético dos fenótipos das células fibrosas e do núcleo do pulposus anelar. A determinação de fatores que influenciam o suprimento e a demanda de nutrientes no IVD aumentará nossa compreensão da patologia IVD e ajudará a elucidar novos alvos terapêuticos para o tratamento da degeneração IVD.

Descritores: Disco intervertebral; Núcleo pulposo; Anel fibroso; Metabolismo energético; Terapia celular.

\section{RESUMEN}

El disco intervertebral (IVD, por sus siglas en inglés) es una de las partes más comúnmente enfermas del cuerpo y solo recientemente nos acercamos a la comprensión de los motivos de su degeneración, de los cuales el suministro de nutrientes juega un papel crucial. En esta revisión de la literatura discutimos los principios básicos y los matices de la oferta y demanda de energía para el IVD. Específicamente, revisamos cómo los diferentes metabolitos influyen en la actividad de las células IVD, los efectos de la carga mecánica sobre el metabolismo de las células IVD y las diferencias en el metabolismo energético de los fenotipos de las células del anillo fibroso y el núcleo pulposo. La determinación de los factores que influyen en la oferta y demanda de nutrientes en el IVD mejorará nuestra comprensión de la patología IVD y ayudará a dilucidar nuevos objetivos terapéuticos para el tratamiento de la degeneración IVD.

Descriptores: Disco intervertebral; Núcleo pulposo; Anillo fibroso; Metabolismo energético; Terapia celular.

\section{INTRODUCTION}

The intervertebral disc (IVD) is one of the parts of the body most commonly affected by disease, and it is only recently that we have come closer to understanding the reasons for its degeneration, in which nutrient supply plays a crucial role. The IVD consists of three primary structures: the nucleus pulposus (NP), which is surrounded radially by the annulus fibrosus $(\mathrm{AF})$, and the cartilaginous endplates (CEP), which attach the disc to the adjoining vertebral bodies. The healthy adult IVD is practically devoid of blood vessels; they are found only in the outer lamellae of the AF. ${ }^{1}$ Nutrients are therefore heavily reliant on diffusive and convective means of transport through disc tissue, with diffusive mechanisms being dominant. ${ }^{2-4}$ The endplates have been shown to be responsible for the majority of nutrient transport into the disc, ${ }^{5}$ though there is some supply originating radially through the AF. ${ }^{1}$ Due to normal aging, the morphology and molecular biology of the disc changes, diminishing its ability to provide critical functions. ${ }^{6,7}$ Within the first decades of life, the disc loses most of its blood supply, resulting in nutrient deficiency. Later, calcification of the CEP leads to the loss of its permeability. ${ }^{8,9}$ This decreases nutrient diffusion, leading to a decrease in glucose and oxygen concentrations and an increase in metabolic waste concentration. The resulting nutrient deprivation and waste product accumulation can lead to cell death and senescence. ${ }^{10}$ Despite making up less than $1 \%$ of the volume of the entire disc, cells are critical for maintaining disc health and function. ${ }^{11}$ Disc cells interact with each other and with the surrounding extracellular matrix, which is constantly being destroyed and rebuilt by the cells as part of the normal tissue repair process. ${ }^{12}$ Cell death in the IVD 
leads to a degradation of the tissue without any ability to repair itself. The aim of this mini-review is to summarize the current literature on IVD nutrient supply and demand. Studying factors that influence nutrient supply and demand in the IVD will enhance our understanding of IVD pathology and elucidate new targets for IVD therapies.

\section{Metabolite Influences on IVD Cell Activity}

Regular glucose supply is critical for IVD cell viability, optimal homeostasis and matrix synthesis. There are several studies that examine the influence of glucose concentration on the proliferation and survival of IVD cells. Cell viability decreases with when glucose concentration is sustained below $0.5 \mathrm{mM}$ for more than three days. ${ }^{13}$ According to another study, ${ }^{14}$ cells begin to die when glucose concentration is sustained below $0.2 \mathrm{mM}$ for 24 hours. It has been shown that the $\mathrm{pH}$ of healthy human discs ranges from 7.1 to $7.4,{ }^{15}$ with a lower $\mathrm{pH}$ in the central part of the disc due to the higher lactic acid accumulation. ${ }^{16}$ Furthermore, the $\mathrm{pH}$ level also harms the condition of the IVD cells: even with an adequate glucose level, the acidic environment adversely affects the viability and proliferation of the cells. ${ }^{17,18}$ During degeneration, the $\mathrm{pH}$ decreases to values of 6.5 to 6.8 in mildly degenerated discs and even to 5.7 in severely degenerated discs. ${ }^{19}$ In vivo, $\mathrm{O} 2$ levels are extremely variable, ranging from $1 \%$ to $5 \%$ within the IVD. ${ }^{20}$

It has been demonstrated that IVD cells could survive at low oxygen concentrations without a significant loss of cell viability.17,21 However, the oxygen consumption rate of degenerated human IVD cells was three to five times higher than that of healthy cells under identical cell culture conditions. ${ }^{22}$ Furthermore, the oxygen consumption rate of degenerated IVD cells was sensitive to glucose levels. However, this study has an important limitation: IVD cells change their phenotype during expansion, ${ }^{23}$ and monolayer expansion induces oxidative metabolism and reactive oxygen species in chondrocytes. ${ }^{24}$

It is widely supported in the literature that an acidic $\mathrm{pH}$ level significantly decreases the rates of glycolysis and oxygen uptake, and as a result, the production of ATP. Proper biosynthesis of extracellular matrix in the IVD requires an extensive amount of ATP to be produced ${ }^{25}$ especially proteoglycan biosynthesis, which uses ATP as an energy source and building block. ${ }^{26}$ Extracellular ATP treatment promoted extracellular matrix accumulation by both cell types and significantly increased intracellular ATP content in NP cells in 3D culture. ${ }^{27}$ In addition, in vitro studies have shown that the synthetic activity of disc cells, i.e. the rate of production of the extracellular matrix depends on the concentration of extracellular oxygen and $\mathrm{pH}$.

The balance between the rate of diffusion of dissolved substances through the matrix and the rate of their consumption by cells determines the concentration gradient within the disc. The concentration gradient in the different regions of disc (i.e. local gradient) has a strong influence on metabolic rates, matrix production and cell survival and hence on the development of disc degeneration. In the disc model proposed by Shirazi-Adl et al., ${ }^{28}$ the zone with the lowest concentrations of oxygen and glucose and maximum level of lactic acid was located in the centre of NP at the disc mid-height plane, which is furthest away from the supply/uptake sources. In this zone, the cells are located 7-8 $\mathrm{mm}$ from the nearest blood vessel. ${ }^{5}$ Thus, the disc central part is likely to be the first part to degenerate due to the nutrient-poor conditions.

Recent studies have demonstrated that NP cells respond to low oxygen concentration and nutrient deprivation by upregulating the synthesis of hypoxia-inducible factor (HIF) proteins, particularly HIF-1 and 2. HIF-1 is known to activate many downstream signals involved in anaerobic metabolism, control of intracellular $\mathrm{pH}$, DNA damage responses and proliferation, and plays an important role in cell adaption, survival, and overcoming the stressful conditions of hypoxia. ${ }^{29-31}$ HIF-1 $\alpha$ has been demonstrated in the NP of both normal and degenerated human IVD ${ }^{32,33}$ and hypoxia responsive glucose transporters GLUT-1, 3, 9 are expressed in NP cells, but not AF and CEP cells. ${ }^{33}$ Furthermore, activation of HIF-1 $\mathrm{C}$ in degenerated IVD increases expression hypoxia responsive glucose transporters GLUT-1, 3, 9 in NP cells. This study shows that NP and AF and CEP cells have different GLUT expression. Based on what is known,
HIF-1 and HIF-2 may also serve to enhance NP cell survival in the specialized microenvironment of the IVD. ${ }^{30-34}$

\section{Effects of Mechanical Loading on the Energy Metabolism of IVD Cells}

Mechanical loading significantly changes water content, chemical composition and nutritional levels in the IVD. The intradiscal pressure varies during normal daily activity, but the effects of abnormal mechanical loading, such as mechanical stresses, hyperflexion and swelling pressure, may lead to injury and degeneration process in IVD. The effects of mechanical loading are dependent on level, loading frequency and permeability capacity of CEP. ${ }^{35}$ It also has been shown that mechanical loading increases glucose and oxygen consumption rates. ${ }^{36,37}$ In a study performed by Fernando et al., ${ }^{38}$ there were no differences in glucose consumption and lactate production of AF cells between the static and dynamic compression groups. Dynamic compression, static compression and vibratory loading all promote ATP release from IVD cells both cell types ${ }^{38,39}$. Therefore, mechanical loading influences the biological function of the IVD by regulating intra- and extra- cellular ATP metabolism. In general, physiological dynamic loading increases oxygen concentration, reduces lactate concentration, and promotes oxygen consumption and lactate production by IVD cells.

\section{Differences in Energy Metabolism of the Annulus Fibrosus and Nucleus Pulposus Cells}

Studies on the metabolism of the IVD suggest that AF and NP are metabolically and bioenergetically different tissues. ${ }^{22,37,38}$ These differences indicate that the main pathway of energy production differs between these types of cells. NP cells consume less glucose and produce much more ATP, which suggests the likely production of ATP by aerobic respiration in addition to glycolysis. ${ }^{40}$ It has been suggested that these differences in cell phenotypes may be attributed to differences in embryonic origins of the tissue types. ${ }^{41}$ The nucleus pulposus is derived from the notochord, whereas AF and CEP arise from the mesenchyme. ${ }^{42}$ The nucleus pulposus contains notochordal cells at early ages, then these cells disappear with age. ${ }^{43}$ The higher lactate production and oxygen rate consumption of the human NP cells indicate that NP cells have a more active metabolic phenotype.

\section{Nutrient Considerations in IVD Therapy}

Currently, treatment strategies for IVD degeneration fail to address the nutrient transport problem faced by cells. The problem of nutrient deprivation can be well illustrated by the significantly higher incidence of smokers with disc degeneration disease. ${ }^{44}$ When confronted with tobacco smoke, human disc cells undergo adverse morphologic changes that suggest a nutrient-deprived state. ${ }^{45}$ One promising technique is that of Hoyland, which utilizes differentiated bone marrow and adipose mesenchymal stem cells to treat disc degeneration. ${ }^{45} \mathrm{How}$ ever, in a nutrient-starved environment, the transplantation of more cells will further reduce the availability of nutrients. In order for therapies to address this starvation, the nutrient transport process must be considered. ${ }^{46}$ Motaghinasab et al. developed a computational model to predict the penetration profile of solutes. In line with the avascular nature of discs, solute concentrations fall dangerously below healthy levels far from the blood supply sources. ${ }^{46}$ Current strategies seek to address this critical nutrient transport deficit through mechanical and biological means such as spinal traction ${ }^{4,47}$ and enzymatic permeabilization ${ }^{48}$ respectively. Kuo et al. explored the effect of spinal traction on molecular transportation in a simulated porcine IVD degeneration model. Though this study, they suggested that traction treatment provides enhancements for nutrition supply. Other studies have offered mixed conclusions about its effectiveness. In response to these challenges, Giers et al. created a porcine model of IVD degeneration to explore biomechanical and physiological factors guiding nutrient transport. Based on the mass transport of dyes, diffusion was determined to be the main transport mechanism. The use of mechanical loading, which includes strategies like spinal traction, was judged as having conflicting benefits for nutrient transportation. ${ }^{4}$ Based on 
these efforts, spinal traction does not appear to address nutrient deprivation, requiring innovative new therapies for degeneration. ${ }^{49}$ Work by Fields et al. explored how changing CEP permeability would influence nutrient diffusion - though nutrient delivery was not clearly improved, this study established a clear correlation. ${ }^{50}$ Therefore, this strategy offers a promising new direction for addressing nutrient transport deficits in IVD.

\section{CONCLUSION}

It should be emphasized that to date, there is no direct evidence of the sequence of these phenomena, evidence of the primary disruption of the IVD trophism and the secondary nature of its degeneration. Further study of the mechanisms determining homeostasis in IVD in normal and pathological tissues is still relevant, since many researchers are already considering the restoration or maintenance of adequate intradiscal metabolism as the determining curative direction for preventing degenerative changes in the IVD.

\section{ACKNOWLEDGEMENTS}

\section{LAB acknowledges scholarship support \#SP-2545.2018.4.}

All authors declare no potential conflict of interest related to this article.

CONTRIBUTION OF THE AUTHORS: Each author made significant individual contributions to this manuscript. VAB (0000-0001-9340-5477)* were the main contributors in the drafting of the manuscript. LAB $(0000-0001-9340-5477)^{\star}$, SO $(0000-0003-3352-6538)^{\star}$, IOM $(0000-0003-3972-8093)^{\star}$ and VAS $(0000-0002-9008-6383)^{*}$ performed the literature search and review of the manuscript and contributed to the intellectual concept of the study. ${ }^{*}$ ORCID (Open Researcher and Contributor ID).

\section{REFERENCES}

1. Nerlich AG, Schaaf R, Walchli B, Boos N. Temporo-spatial distribution of blood vessels in human lumbar intervertebral discs. Eur Spine J. 2007:16(4):547-55.

2. Mauck RL, Hung CT, Ateshian GA. Modeling of neutral solute transport in a dynamically loaded porous permeable gel: implications for articular cartilage biosynthesis and tissue engineering. J Biomech Eng. 2003;125(5):602-14.

3. Gullbrand SE, Peterson J, Mastropolo R, Roberts TT, Lawrence JP, Glennon JC et al. Low rate loading-induced convection enhances net transport into the intervertebral disc in vivo. Spine J. 2015;15(5):1028-33.

4. Giers MB, Munter BT, Eyster KJ, Ide GD, Newcomb A, Lehrman JN et al. Biomechanical and Endplate Effects on Nutrient Transport in the Intervertebral Disc. World Neurosurg. 2017;99:395-402.

5. Urban JP, Smith S, Fairbank JC. Nutrition of the intervertebral disc. Spine (Phila Pa 1976). 2004;29(23):2700-9.

6. Vo NV, Hartman RA, Patil PR, Risbud MV, Kletsas D, latridis JC et al. Molecular mechanisms of biological aging in intervertebral discs. J Orthop Res. 2016;34(8):1289-306.

7. Li W, Wang P, Zhang Z, Wang W, LiuY, Oi O. MiR-184 Regulates Proliferation in Nucleus Pulposus Cells by Targeting GAS1. World Neurosurg. 2017;97:710-5.

8. Hangai M, Kaneoka K, Kuno S, Hinotsu S, Sakane M, Mamizuka N et al. Factors associated with lumbar intervertebral disc degeneration in the elderly. Spine J. 2008:8(5):732-40.

9. DeLucca JF, Cortes DH, Jacobs NT, Vresilovic EJ, Duncan RL, Elliott DM. Human cartilage endplate permeability varies with degeneration and intervertebral disc site. J Biomech. 2016;49(4):550-7.

10. Huang YC, Urban JP, Luk KD. Intervertebral disc regeneration: do nutrients lead the way? Nat Rev Rheumatol. 2014;10(9):561-6.

11. Hohaus C, Ganey TM, Minkus Y, Meisel HJ. Cell transplantation in lumbar spine disc degeneration disease. Eur Spine J. 2008;17 Suppl 4:492-503.

12. Gruber HE, Leslie K, Ingram J, Hoelscher G, Norton HJ, Hanley EN Jr. Colony formation and matrix production by human anulus cells: modulation in three-dimensional culture. Spine (Phila Pa 1976). 2004:29(13):E267-74.

13. Horner HA, Urban JP. 2001 Volvo Award Winner in Basic Science Studies: Effect of nutrient supply on the viability of cells from the nucleus pulposus of the intervertebral disc. Spine (Phila Pa 1976). 2001;26(23):2543-9.

14. Windhaber RA, Wilkins RJ, Meredith D. Functional characterisation of glucose transport in bovine articular chondrocytes. Pflugers Arch. 2003:446(5):572-7.

15. Diamant B, Karlsson J, Nachemson A. Correlation between lactate levels and pH in discs of patients with lumbar rhizopathies. Experientia. 1968;24(12):1195-6.

16. Urban JP. The role of the physicochemical environment in determining disc cell behaviour. Biochem Soc Trans. 2002:30(Pt 6):858-64.

17. Bibby SR, Jones DA, Ripley RM, Urban JP. Metabolism of the intervertebral disc: effects of low levels of oxygen, glucose, and $\mathrm{pH}$ on rates of energy metabolism of bovine nucleus pulposus cells. Spine (Phila Pa 1976). 2005;30(5):487-96.

18. Liang CZ, Li H, Tao YQ, Zhou XP, Yang ZR, Li FC et al. The relationship between low pH in intervertebral discs and low back pain: a systematic review. Arch Med Sci. 2012;8(6):952-6.

19. Gilbert HT, Hodson N, Baird P, Richardson SM, Hoyland JA. Acidic pH promotes intervertebral disc degeneration: Acid-sensing ion channel -3 as a potential therapeutic target. Sci Rep. 2016:6:37360.

20. Ishihara H, Urban JP. Effects of low oxygen concentrations and metabolic inhibitors on proteoglycan and protein synthesis rates in the intervertebral disc. J Orthop Res. 1999;17(6):829-35

21. Bibby SR, Urban JP. Effect of nutrient deprivation on the viability of intervertebral disc cells. Eur Spine J. 2004:13(8):695-701.

22. Cisewski SE, WuY, Damon BJ, Sachs BL, Kern MJ, Yao H. Comparison of Oxygen Consumption Rates of Nondegenerate and Degenerate Human Intervertebral Disc Cells. Spine (Phila Pa 1976). 2018;43(2):E60-7.

23. Tang $X$, Richardson WJ, Fitch RD, Brown CR, Isaacs RE, Chen J. A new non-enzymatic method for isolating human intervertebral disc cells preserves the phenotype of nucleus pulposus cells. Cytotechnology. 2014;66(6):979-86

24. Heywood HK, Lee DA. Monolayer expansion induces an oxidative metabolism and ROS in chondrocytes. Biochem Biophys Res Commun. 2008:373(2):224-9.

25. Wang $C$, Huang CY, Lin WC. Optical ATP biosensor for extracellular ATP measurement. Biosens Bioelectron. 2013;43:355-61.

26. Croucher LJ, Crawford A, Hatton PV, Russell RG, Buttle DJ. Extracellular ATP and UTP stimulate cartilage proteoglycan and collagen accumulation in bovine articular chondro- cyte pellet cultures. Biochim Biophys Acta. 2000;1502(2):297-306

27. Gonzales S, Wang C, Levene H, Cheung HS, Huang CC. ATP promotes extracellular matrix biosynthesis of intervertebral disc cells. Cell Tissue Res. 2015;359(2):635-42.

28. Shirazi-Adl A, Taheri M, Urban JP. Analysis of cell viability in intervertebral disc: Effect of endplate permeability on cell population. J Biomech. 2010;43(7):1330-6.

29. Culver C, Melvin A, Mudie S, Rocha S. HIF-1alpha depletion results in SP1-mediated cell cycle disruption and alters the cellular response to chemotherapeutic drugs. Cell Cycle. 2011:10(8):1249-60.

30. Li H, Liang CZ, Chen QX. Regulatory role of hypoxia inducible factor in the biological behavior of nucleus pulposus cells. Yonsei Med J. 2013;54(4):807-12.

31. Agrawal A, Guttapalli A, Narayan S, Albert TJ, Shapiro IM, Risbud MV. Normoxic stabilization of HIF-1alpha drives glycolytic metabolism and regulates aggrecan gene expression in nucleus pulposus cells of the rat intervertebral disk. Am J Physiol Cell Physiol. 2007;293(2):C621-31

32. Ha KY, Koh IJ, Kirpalani PA, Kim YY, Cho YK, Khang GS et al. The expression of hypoxia inducible factor-1alpha and apoptosis in herniated discs. Spine (Phila Pa 1976). 2006:31(12):1309-13.

33. Richardson SM, Knowles R, Tyler J, Mobasheri A, Hoyland JA. Expression of glucose transporters GLUT-1, GLUT-3, GLUT-9 and HIF-1alpha in normal and degenerate human intervertebral disc. Histochem Cell Biol. 2008;129(4):503-11.

34. Risbud MV, Schipani E, Shapiro IM. Hypoxic regulation of nucleus pulposus cell survival: from niche to notch. Am J Pathol. 2010;176(4):1577-83.

35. WuY, Cisewski SE, Wegner N, Zhao S, Pellegrini VD Jr., Slate EH et al. Region and strain-dependent diffusivities of glucose and lactate in healthy human cartilage endplate. J Biomech. 2016:49(13):2756-62.

36. Huang $C Y, G u W Y$. Effects of mechanical compression on metabolism and distribution of oxygen and lactate in intervertebral disc. J Biomech. 2008:41(6):1184-96.

37. Salvatierra JC, Yuan TY, Fernando H, Castillo A, Gu WY, Cheung HS et al. Difference in Energy Metabolism of Annulus Fibrosus and Nucleus Pulposus Cells of the Intervertebral Disc. Cell Mol Bioeng. 2011;4(2):302-10.

38. Fernando HN, Czamanski J, Yuan TY, GuW, Salahadin A, Huang CY. Mechanical loading affects the energy metabolism of intervertebral disc cells. J Orthop Res. 2011;29(11):1634-41.

39. Yamazaki S, Weinhold PS, Graff RD, Tsuzaki M, Kawakami M, Minchew JT et al. Annulus cells release ATP in response to vibratory loading in vitro. J Cell Biochem. 2003:90(4):812-8.

40. Wang C, Gonzales S, Levene H, Gu W, Huang CY. Energy metabolism of intervertebral disc under mechanical loading. J Orthop Res. 2013;31(11):1733-8.

41. Pattappa G, Li Z, Peroglio M, Wismer N, Alini M, Grad S. Diversity of intervertebral disc cells: phenotype and function. J Anat. 2012:221(6):480-96.

42. Zhao CQ, Wang LM, Jiang LS, Dai LY. The cell biology of intervertebral disc aging and degeneration. Ageing Res Rev. 2007;6(3):247-61.

43. Guehring T, Wilde G, Sumner M, Grunhagen T, Karney GB, Tirlapur UK et al. Notochordal intervertebral disc cells: sensitivity to nutrient deprivation. Arthritis Rheum. 2009:60(4):1026-34

44. Jakoi AM, Pannu G, D’Oro A, Buser Z, Pham MH, Patel NN et al. The Clinical Correlations between Diabetes, Cigarette Smoking and Obesity on Intervertebral Degenerative Disc Disease of the Lumbar Spine. Asian Spine J. 2017;11(3):337-47.

45. Hoyland JA, Clarke L, Hodgkinson T, Richardson SM. Mesenchymal Stem Cell Based Therapies for Disc Repair/Regeneration. Global Spine Journal. 2016;6(1_ suppl):s-0036-1582585.

46. Motaghinasab S, Shirazi-Adl A, Urban JP, Parnianpour M. Computational pharmacokinetics of solute penetration into human intervertebral discs - effects of endplate permeability, solute molecular weight and disc size. J Biomech. 2012;45(13):2195-202.

47. KuoYW, Hsu YC, Chuang IT, Chao PH, Wang JL. Spinal traction promotes molecular transportation in a simulated degenerative intervertebral disc model. Spine (Phila Pa 1976). 2014;39(9):E550-6.

48. Fields AJ, Ouyang A, Tang X, Lotz JC. Influence of Cartilage Endplate Permeability on Intervertebral Disc Nutrition. ORS 2016 Annual Meeting Paper No 0308;2016.

49. Byvaltsev VA, Kolesnikov SI, Belykh EG, Stepanov IA, Kalinin AA, Bardonova LA et al. Complex Analysis of Diffusion Transport and Microstructure of an Intervertebra Disk. Bull Exp Biol Med. 2017;164(2):223-8.

50. Belykh EG, Kalinin AA, Patel AA, Miller EJ, Bohl MA, Stepanov IA et al. Apparent diffusion coefficient maps in the assessment of surgical patients with lumbar spine degeneration. PLoS One. 2017;12(8):e0183697. 